\title{
Ocena uzasadnionego wniosku, zgodnie z art. 7 Traktatu o Unii Europejskiej, dotyczącego praworządności w Polsce, wraz z projektem decyzji Rady w sprawie stwierdzenia wyraźnego ryzyka poważnego naruszenia przez Rzeczpospolitą Polską zasady praworządności ${ }^{1}$
}

\begin{abstract}
The assessment of the justified application, in accordance with Article 7 of the Treaty on European Union, concerning the rule of law in Poland, together with the draft Council decision on stating the clear risk of a serious violation of the rule of law by the Republic of Poland: Having assessed the EU documents, the author states that the proposed decision does not have social, economic or financial consequences. When assessing documents legally, the author states that the recommendations and the determination of a clear risk are two separate acts of the Council, the recommendations of which are a an act adopted prior to the one concerning the identification of the clear risk. Consequently, the recommendations cannot be part of the statement of a clear risk. The defective nature of the Commission's proposed decision makes it difficult to assess the impact. The contradiction of this decision with the TEU should be challenged by the European Parliament during the consent procedure or by the Court of Justice in the course of the follow-up procedure.
\end{abstract}

Keywords: European Union | protection of the rule of law | Poland

Słowa kluczowe: Unia Europejska | ochrona praworządności | Polska

1 Opinia na temat uzasadnionego wniosku zgodnie z art. 7 Traktatu o Unii Europejskiej dotyczącego praworządności w Polsce, wraz z projektem decyzji Rady w sprawie stwierdzenia wyraźnego ryzyka poważnego naruszenia przez Rzeczpospolita Polska zasady praworządności (COM(2017) 835 final) sporządzona 8 lutego 2018 r. na zlecenie przewodniczącej Komisji ds. Unii Europejskiej; BAS-WAPM 78/18. 


\section{Opinia merytoryczna}

\section{Przedmiot dokumentów UE}

\section{- Treść dokumentów UE}

Opiniowany dokument został sformułowany w trybie art. 7 ust. 1 Traktatu o Unii Europejskiej (TUE). Składa się z pięciu części i dołączonego projektu decyzji Rady Unii Europejskiej w sprawie stwierdzenia wyraźnego ryzyka poważnego naruszenia przez Rzeczpospolitą Polską zasady praworządności (2017/0360, NLE). Uzasadniony wniosek (powinno być: uzasadniona propozycja ${ }^{2}$ ) rozpoczyna się wprowadzeniem, w którym m.in. nawiązuje się do pojmowania zasady praworządności (pkt 2), a zatem wzorca oceny dokonanej przez Komisję, krótkiego opisu art. 7 ust. 1 TUE i podstawowych obaw Komisji związanych z sytuacją w Polsce.

W części drugiej Komisja charakteryzuje okoliczności faktyczne i przebieg postępowania, którego zwieńczeniem jest opiniowany uzasadniony wniosek. Jest to stosunkowo najbardziej rozbudowany fragment wniosku. Komisja wskazała, że rozwój wypadków w Polsce związanych z zasadą praworządności Komisja śledzi i podejmuje odpowiednie działania od listopada 2015 r. Jako podstawę swojej aktywności wskazała komunikat skierowany do Parlamentu Europejskiego i Rady z 11 marca 2014 r. pt. Nowe ramy UE na rzecz umocnienia praworządności $i^{3}$. W dokumencie tym ustanowiła trójetapową procedurę dotyczącą, w jej rozumieniu, dialogu z państwem członkowskim. Procedura ta obejmuje: a) ocenę Komisji; b) zalecenie w sprawie praworządności; c) działania następcze w stosunku do zalecenia w sprawie praworządności. W części drugiej Komisja scharakteryzowała także działania władz polskich, w szczególności parlamentu i Prezydenta RP, przede wszystkim w odniesieniu do Trybunału Konstytucyjnego i sądownictwa. Przedstawiła też działania, jakie Komisja i inne podmioty (Parlament Europejski, europejskie zrzeszenia organów sądowych czy palestry, ale także Komisja Wenecka Rady Europy i inne organy Rady, inne podmioty międzynarodowe, zwłaszcza związane z ONZ, OBWE, niektóre polskie organy państwowe, jak Sąd Najwyższy czy Rzecznik Praw Obywatelskich, a także inne zainteresowane podmioty) podejmowały wobec sytuacji w Polsce w zakresie poszanowania zasady praworządności. Komisja skoncentrowała uwagę na swojej opinii na sprawie praworządności w Polsce z 1 czerwca 2016 r., a zwłaszcza na

2 Tłumaczenia traktatów są wadliwe w zakresie, w jakim termin „proposal”, „proposition” tłumaczą jako wniosek, a nie propozycja (ewentualnie projekt), ponieważ termin „wniosek” w polskim języku prawnym i prawniczym nie obejmuje projektów aktów czy propozycji legislacyjnych lub politycznych. Podobnie zresztą w prawie Unii Europejskiej „wniosek” (motion) odnosi się do działań proceduralnych. Tymczasem "propozycja” jest odniesiona wyłącznie do działań w postaci aktów prawnych.

$3 \operatorname{COM}(2014) 158$ final. 
trzech dotychczasowych zaleceniach z lat 2016-2017, które były publikowane w Dzienniku Urzędowym Unii Europejskiej4. Komisja przypomina w tym kontekście różne działania i akty władz polskich, które oceniła krytycznie.

W tym kontekście wskazała dwie grupy uchybień w sferze praworządności. Pierwsza z nich dotyczy braku niezależnej i zgodnej z prawem kontroli zgodności z Konstytucją RP. Naruszenia zaliczone do tej grupy stanowią część trzecią opinii. Koncentrują się one wokół Trybunału Konstytucyjnego (TK). Komisja wymienia m.in.: niedopuszczenie do objęcia funkcji sędziego przez trzech wybranych przez Sejm poprzedniej kadencji sędziów, włączenie do składu TK sędziów wadliwie wybranych, wadliwe wybory prezesa i wiceprezesa TK, zmiany w składach orzekających. Komisja uznała wręcz, że te działania spowodowały: całkowita zmiane składu TK poza zwyktym konstytucyjnym procesem powoływania sędziów. Następnie Komisja wskazała postępowanie wobec Trybunału (nieopublikowanie i niewykonanie niektórych wyroków TK), które spowodowało, że utracił on swoją legitymację i że: nie można już zagwarantować zgodności polskich przepisów prawa $z$ ustawa zasadniczą, co ma szczególne znaczenie w związku z jednoczesnym uchwaleniem przez Sejm ustaw we wrażliwych dziedzinach (s. 20). Komisja podkreśla, że nie zostały wykonane żadne z działań zalecanych przez Komisję.

Część czwartą uzasadnionego wniosku wypełniają ustalenia dotyczące zagrożeń dla niezależności sądów powszechnych (w gruncie rzeczy wymiaru sprawiedliwości). Mowa tutaj zwłaszcza o uchybieniach, jakie w rozumieniu Komisji popełniły władze polskie w stosunku do Sądu Najwyższego (SN), tj. obniżenie wieku emerytalnego i odwołanie i obowiązkowe przeniesienie w stan spoczynku obecnych około 37\% sędziów SN, prawo Prezydenta RP do przedłużenia kadencji sędziego na wniosek zainteresowanego, wprowadzenie skargi nadzwyczajnej, wprowadzenie szczególnego postępowania dyscyplinarnego, ustanowienie dwóch nowych izb do SN, o szczególnej względem pozostałych pozycji ustrojowej i budżetowej, Krajowej Rady Sądownictwa (KRS), tj. skrócenie kadencji członków KRS, nowy sposób wyboru jej członków, i sądów powszechnych, tj. obniżenie wieku emerytalnego, upoważnienie Ministra Sprawiedliwości do przedłużania kadencji, uprawnienia Ministra Sprawiedliwości w zakresie odwoływania i powoływania prezesów sądów powszechnych, możliwość stosowania przez Ministra Sprawiedliwości dyscyplinującego okresowego obniżenia dodatku funkcyjnego prezesom sądów powszechnych. Ponadto Komisja zwróciła uwagę na niepokojące, jej zdaniem, zmiany w odniesieniu do Krajowej Szkoły Sądownictwa i dopuszczenia asesorów do orzekania, prokura-

4 Zalecenia nr 2016/1374 z 27 lipca 2016 r. (Dz.Urz. UE L 217, s. 53); nr 2017/146 z 21 grudnia 2016 r. (Dz.Urz. UE L 22, s. 65); nr 2017/1520 z 26 lipca 2017 r. (Dz.Urz. UE L 228, s. 19). Podstawą tych zaleceń był art. 292 Traktatu o funkcjonowaniu Unii Europejskiej. 
tury, łącznie ze sprawą połączenia stanowiska Ministra Sprawiedliwości i Prokuratora Generalnego.

Ostatnia, piąta część uzasadnionego wniosku zawiera argumentację na rzecz stwierdzenia istnienia wyraźnego ryzyka poważnego naruszenia zasady praworządności. Komisja wskazała, że mimo zaleceń sytuacja stale ulega pogorszeniu. Zmiany w TK i działania z nim związane podważyły, w jej ujęciu, niezależność i legitymację TK i wykluczyły skuteczną kontrolę konstytucyjności prawa w Polsce. Ustawodawstwo i działania dotyczące SN z kolei doprowadziły do: strukturalnego osłabienia niezawisłości sędziów Sądu Najwyższego, budzą zastrzeżenia dotyczące zasady podziału władz (zwłaszcza w powiązaniu z równoległą reformą KRS), a w zakresie wprowadzenia skargi nadzwyczajnej podważają zasady pewności prawa i podziału władz. W przypadku sądów powszechnych Polska uchybiła zasadzie nieusuwalności sędziów, która jest podstawowym elementem zasady niezawisłości sędziów, a przez swobodne powoływanie i odwoływanie prezesów sądów także zasadzie niezależności władzy sądowniczej. Zasady te naruszono również w związku ze zmianami dotyczącymi KRS. Komisja podkreśliła w kontekście tych zarzutów, że władze polskie nie wykorzystały okazji, aby uwzględnić obawy Komisji i innych podmiotów, co dowodzi braku dobrej woli z ich strony. Wreszcie Komisja stwierdziła, że działania władz polskich powodują poważne konsekwencje: a) brak możliwości skutecznego skontrolowania konstytucyjności nowego „wrażliwego” ustawodawstwa; b) naruszanie zasady praworządności uniemożliwia należyte wypełnianie praw i obowiązków traktatowych, a także podważa wzajemne zaufanie przedsiębiorstw i organów krajowych do systemów prawnych; c) zakłócenia w zakresie należytego funkcjonowania praworządności są szkodliwe dla rynku wewnętrznego i działań obszaru wolności, bezpieczeństwa i sprawiedliwości (niezależne sądownictwo to warunek współpracy sądów $\mathrm{z}$ różnych państw członkowskich).

W zakończeniu uzasadnionego wniosku Komisja stwierdza, że jest gotowa w każdej chwili ponownie go rozważyć, jeżeli władze polskie wykonają działania, które Komisja wskazała w wydanym jednocześnie z wnioskiem zaleceniu, w terminie w nim określonym, tj. 3 miesięcy od daty otrzymania tego zalecenia (pkt 49) $)^{5}$.

Ostatnim elementem uzasadnionego wniosku jest projekt decyzji Rady w sprawie stwierdzenia wyraźnego ryzyka poważnego naruszenia przez Rzeczpospolitą Polską zasady praworządności. Komisja referuje w nim w skrótowy sposób przyczyny, jakie, jej zdaniem, doprowadzają Radę do przyjęcia decyzji, a w części operatywnej formułuje dwa przepisy. W pierwszym z nich stwierdza wystąpienie wyraźnego ryzyka poważnego naruszenia zasady praworządności przez Polskę, a w drugim zaleca, aby Polska podjęła następujące działania w terminie trzech miesięcy od daty notyfikacji decyzji:

5 Zalecenie nr 2018/103 z 20 grudnia 2017 r., Dz.Urz. UE L 17 z 2018 r., s. 50. 
- przywróciła niezależność i legitymację Trybunału Konstytucyjnego jako gwaranta Konstytucji RP przez zapewnienie, aby prezes, wiceprezes oraz sędziowie Trybunału byli wybierani i powoływani zgodnie z prawem, oraz przez pełne wykonanie wyroków TK z 3 i 9 grudnia 2015 r., zgodnie z którymi stanowiska sędziów TK ma objąć trzech sędziów wybranych zgodnie z prawem przez Sejm poprzedniej kadencji w październiku 2015 r., a trzech sędziów wybranych przez Sejm nowej kadencji bez ważnej podstawy prawnej nie może orzekać, dopóki nie zostaną wybrani zgodnie z prawem,

- opublikowała i w pełni wykonała wyroki TK z 9 marca 2016 r., 11 sierpnia 2016 r. $i 7$ listopada 2016 r.,

- zagwarantowała, aby ustawa o Sądzie Najwyższym, ustawa - Prawo o ustroju sądów powszechnych, ustawa o Krajowej Radzie Sądownictwa oraz ustawa o Krajowej Szkole Sądownictwa zostały zmienione w taki sposób, aby zapewniono ich zgodność z wymogami w zakresie niezależności sądów i niezawisłości sędziów, podziału władz i pewności prawa,

- zagwarantowała, aby wszelka reforma sądownictwa była przygotowywana w ścisłej współpracy z przedstawicielami sądownictwa i wszystkimi zainteresowanymi stronami, w tym z Komisją Wenecką,

- powstrzymała się od działań i oświadczeń publicznych, które naruszają legitymację TK, SN, sądów powszechnych, sędziów, zarówno konkretnych osób, jak i sędziów ogółem, oraz wymiaru sprawiedliwości jako całości.

Wymienione zalecenia są zbieżne z zaleceniem Komisji z 20 grudnia 2017 r. (pkt 47).

\section{- Geneza dokumentów UE}

Komisja przedstawiła uzasadniony wniosek po dwóch latach od rozpoczęcia procedury praworządności, jaką przeprowadziła zgodnie z komunikatem z 2014 r., w przekonaniu, że: $w$ dużym stopniu wykorzystała możliwości przewidziane $w$ ramach na rzecz umocnienia praworządności w celu konstruktywnego dialogu $z$ polskimi władzami, po wymianie z nimi ponad 25 pism i odbyciu licznych spotkań (s. 3).

\section{Ocena dokumentów UE}

\section{- Ocena skutków społecznych, gospodarczych i finansowych dokumentów UE}

Projektowana decyzja nie wywołuje skutków społecznych, gospodarczych ani finansowych. W odniesieniu do skutków prawnych zob. uwagi zawarte w części Opinia prawna niniejszego opracowania. 


\section{- Ocena zgodności działań UE z zasadą pomocniczości}

Projektowana decyzja nie podlega ocenie pod względem zgodności z zasadą pomocniczości, ponieważ nie jest ona projektem aktu prawodawczego Unii Europejskiej ${ }^{6}$.

\section{- Ustosunkowanie się do projektu stanowiska Rady Ministrów na temat opiniowanych dokumentów UE}

Do momentu sporządzenia tej opinii Rada Ministrów nie przedstawiła projektu stanowiska RP w sprawie uzasadnionej opinii i projektu decyzji Rady.

\section{Opinia prawna}

\section{Podstawa prawna projektowanej decyzji Rady Unii Europejskiej}

Opiniowany dokument ma charakter szczególny, ponieważ zawiera pierwszy w historii procesu integracji europejskiej uzasadniony wniosek wszczynający procedurę, o której mowa w art. 7 TUE, stosowania środków wobec państw członkowskich w razie zagrożenia naruszenia lub naruszenia przez nie wartości, o których mowa w art. 2 TUE, obejmujący także projekt decyzji Rady Unii Europejskiej w sprawie stwierdzenia wyraźnego ryzyka poważnego naruszenia przez Rzeczpospolitą Polską zasady praworządności.

Określenia podstawy prawnej wymaga bez wątpienia decyzja Rady, której projekt został załączony do uzasadnionej opinii. Podstawa taka stanowi bowiem regułę wyrażającą kompetencję Unii do działania wobec państw członkowskich w szczególnym trybie. Jak wskazała Komisja w swoim projekcie, podstawą prawną przyszłej decyzji Rady w sprawie stwierdzenia wyraźnego ryzyka poważnego naruszenia przez Rzeczpospolitą Polską zasady praworządności ma być art. 7 ust. 1 TUE.

Projektowana decyzja składa się z preambuły, stanowiącej skrócone uzasadnienie przyjęcia decyzji, odwołujące się jednak do obszernego uzasadnionego wniosku (tak w części wstępnej, jak i w treści preambuły), i dwóch artykułów, z których pierwszy stwierdza istnienie wyraźnego ryzyka naruszenia przez Polskę zasady praworządności, a drugi zawiera pięć zaleceń skierowanych do Polski, które powinny być spełnione w terminie trzech miesięcy od daty notyfikacji decyzji.

W świetle art. 7 ust. 1 TUE projekt decyzji obarczony jest istotną wadą prawną. Polega ona na błędnej interpretacji tego postanowienia. W projektowanej decyzji doszło bowiem do połączenia dwóch aktów, jakie powinna przyjąć Rada. Artykuł 7 ust. 1 TUE stanowi bowiem, że: [n] a uzasadniony wniosek jednej trze-

6 O rozumieniu aktu prawodawczego zob. szerzej opinia C. Mika na temat pojmowania aktów ustawodawczych i znaczenia tego pojęcia dla pozycji parlamentów narodowych w Unii Europejskiej, „Zeszyty Prawnicze BAS” 2010, nr 2, s. 96 i n. 
ciej państw członkowskich, Parlamentu Europejskiego lub Komisji Europejskiej, Rada, stanowiąc większością czterech piątych swych członków po uzyskaniu zgody Parlamentu Europejskiego, może stwierdzić istnienie wyraźnego ryzyka poważnego naruszenia przez państwo członkowskie wartości, o których mowa w artykule 2. Przed dokonaniem takiego stwierdzenia Rada wysłuchuje dane państwo członkowskie $i$, stanowiąc zgodnie z ta sama procedura, może skierować do niego zalecenia.

Rada regularnie bada, czy powody dokonania takiego stwierdzenia pozostaja aktualne ${ }^{7}$.

Z zacytowanego postanowienia wynika określona sekwencja działania. Polega ona na tym, że stwierdzenie wyraźnego ryzyka ma poprzedzić wysłuchanie obwinianego o naruszenie art. 2 TUE państwa członkowskiego, po którym może (nie musi) dojść do sformułowania przez Radę zaleceń dla państwa członkowskiego ${ }^{8}$. Po wysłuchaniu państwa członkowskiego i ewentualnym (bezskutecznym) skierowaniu do niego zaleceń Rada może stwierdzić istnienie wyraźnego ryzyka. Stwierdzenie to powinno podawać powody, które do niego doprowadziły i które później będą mogły być (regularnie) weryfikowane co do tego, czy trwają nadal, czy też ustały. Cytowane postanowienie wymaga, aby zarówno przyjęcie zaleceń, jak i stwierdzenie wyraźnego ryzyka odbyło się „w tej samej procedurze”, opisanej w ust. 1. Jeżeli zatem Rada zamierzałaby przyjąć zalecenie, to najpierw

7 W wersjach w jęz. angielskim i francuskim brzmienie art. 7 ust. 1 TUE (zwłaszcza zdanie drugie) jest bardziej precyzyjne. Łączy się tutaj jednoznacznie uprzedniość wysłuchania i wydanie zaleceń, wymagając przeprowadzenia takiej samej procedury: 1) ang.: 1. On a reasoned proposal by one third of the Member States, by the European Parliament or by the European Commission, the Council, acting by a majority of four fifths of its members after obtaining the consent of the European Parliament, may determine that there is a clear risk of a serious breach by a Member State of the values referred to in Article 2. Before making such a determination, the Council shall hear the Member State in question and may address recommendations to it, acting in accordance with the same procedure.

The Council shall regularly verify that the grounds on which such a determination was made continue to apply.

2) fr.: 1. Sur proposition motivée d'un tiers des États membres, du Parlement européen ou de la Commission européenne, le Conseil, statuant à la majorité des quatre cinquièmes de ses membres après approbation du Parlement européen, peut constater qu'il existe un risque clair de violation grave par un État membre des valeurs visées à l'article 2. Avant de procéder à cette constatation, le Conseil entend l'État membre en question et peut lui adresser des recommandations, en statuant selon la même procédure.

Le Conseil vérifie régulièrement si les motifs qui ont conduit à une telle constatation restent valables.

8 W doktrynie niemieckiej zauważa się, że w zdaniu drugim art. 7 ust. 1 TUE przyjęto rozwiązanie w istocie dyplomatyczne, pozwalając Radzie przyjąć niewiążące zalecenia. Tak M. Ruffert w komentarzu do art. 7 [w:] E. Grabnitz, M. Hilf, M. Nettesheim, Das Recht der Europäischen Union, München 2012-2014, s. 9-10. 
uprawnione podmioty musiałyby jej przedłożyć uzasadniony wniosek, po czym Rada powinna wysłuchać państwo członkowskie, wreszcie podjąć uchwałę większością 4/5 członków Rady, uzyskując wcześniej zgodę Parlamentu Europejskiego. Procedura ta musiałaby zostać powtórzona w przypadku stwierdzenia istnienia wyraźnego ryzyka. Możliwe jest oczywiście nieformułowanie zaleceń, lecz od razu, aczkolwiek po wysłuchaniu państwa członkowskiego i uzyskaniu zgody Parlamentu Europejskiego, stwierdzenie istnienia wyraźnego ryzyka.

Artykuł 7 ust. 1 TUE nie precyzuje w pełni formy działania Rady. Wskazuje tylko, że Rada może udzielać zaleceń oraz stwierdzać istnienie wyraźnego ryzyka ${ }^{9}$. Należy jednak przyjąć, że udzielenie zalecenia nie może przybrać formy decyzji, ponieważ wzruszałoby to naturę zalecenia jako aktu prawnie niewiążącego. Zalecenie ma skłonić, a nie zobowiązywać, do działania. I jest tak nawet wtedy, gdy łączy się z określeniem terminu wykonania zaleceń (aczkolwiek w art. 7 ust. 1 TUE nie mówi się wyraźnie, że Rada ma kompetencję do udzielenia zalecenia, które ustalałoby termin zastosowania się państwa członkowskiego do zaleceń). Zalecenie zostaje także w art. 7 ust. 1 TUE nazwane (nie chodzi tutaj o zalecenie w postaci materialnej, lecz o formę zalecenia). Jest ono aktem formalnym w rozumieniu art. 288 Traktatu o funkcjonowaniu Unii Europejskiej (TFUE), różnym od decyzji (porównaj akapity 4 i 5 tego postanowienia).

Także w przypadku stwierdzenia wyraźnego TUE nie przesądza jego formy. W gruncie rzeczy sam akt również może się nazywać „stwierdzeniem wyraźnego ryzyka”, ewentualnie uchwałą w tej sprawie. W końcu procedura ma charakter szczególny, umiejscowiona jest w TUE, a nie TFUE, co skłaniałoby do korzystania z formalnych aktów, o których mowa w art. 288 TFUE. Ponadto inaczej niż np. w ust. 3 i 4 art. 7 TUE, gdzie wyraźnie mowa o decydowaniu, i inaczej niż w wielu innych postanowieniach TUE, nie wspomina się tutaj o decyzji jako formie aktu Rady. Do takiego wniosku prowadzi także lektura art. 269 TFUE ${ }^{10}$. Mówi się tutaj o skardze do Trybunału Sprawiedliwości, jaka przysługuje państwu członkow-

9 W doktrynie podkreśla się, że mechanizm nadzorczy, o którym mowa w art. 7 TUE, ma charakter polityczny, a nie prawny, a same ustalenia wyraźnego ryzyka i naruszenia mają naturę uznaniową. Zob. np. F.-X. Priollaud, D. Siritzky, Le Traité de Lisbonne. Texte et commentaire article par article des nouvaux traités européens (TUE-TFUE), Paris 2008, s. 49. W innym ujęciu mówi się, że jest to mechanizm wczesnego ostrzegania, odmienny od procedury sankcji, o którym mowa w art. 7 ust. 2 TUE. Zob. R. Geiger w komentarzu do art. 7 Traktatu o Unii Europejskiej [w:] European Union Treaties. A Commentary. Treaty on European Union. Treaty on the Functioning of the European Union. Charter of Fundamental Rights of the European Union, red. R. Geiger, D.-E. Khan, M. Kotzur, München-Oxford 2015, s. 60-61.

10 Art. 269 TFUE brzmi następująco:

1) pol.: Trybunał Sprawiedliwości jest właściwy do orzekania w sprawie legalności aktu przyjętego przez Rade Europejska lub Radę zgodnie z artykułem 7 Traktatu o Unii Europejskiej wyłącznie na wniosek Państwa Członkowskiego, którego dotyczy 
skiemu, wobec którego zastosowano art. 7 TUE. W postanowieniu tym używa się terminu „akt” jako równoważny określeniu „stwierdzenie” Rady Europejskiej lub Rady. Skarga może dotyczyć legalności aktu wyłącznie w zakresie procedury jego przyjęcia ${ }^{11}$, co sprawia, że natura samego aktu (prawna czy polityczna) pozostaje nierozstrzygnięta.

W przypadku stwierdzenia wyraźnego ryzyka należy oczekiwać, że Rada jednocześnie ustali termin, w którym dokona ponownej oceny co do tego, czy powody stwierdzenia uległy zmianie (skoro ma badać sprawę regularnie). Zarazem z ustalenia, że sprawa jest badana regularnie, wynika logiczny wniosek, że państwo członkowskie musi mieć pewien czas na usunięcie podstaw stwierdzenia wyraźnego ryzyka.

$\mathrm{Z}$ przedstawionego rozumowania wynika, że zalecenia i stwierdzenie wyraźnego ryzyka stanowią dwa odrębne akty Rady, z których zalecenia są aktem uprzednim wobec stwierdzenia wyraźnego ryzyka ${ }^{12}$. W konsekwencji zalecenia

stwierdzenie Rady Europejskiej lub Rady, oraz wyłacznie w odniesieniu do przestrzegania postanowień czysto proceduralnych przewidzianych $w$ tym artykule.

Wniosek taki musi być złożony w terminie miesiaca od daty tego stwierdzenia. Trybunat orzeka $w$ terminie miesiaca od daty wniosku.

2) ang.: The Court of Justice shall have jurisdiction to decide on the legality of an act adopted by the European Council or by the Council pursuant to Article 7 of the Treaty on European Union solely at the request of the Member State concerned by a determination of the European Council or of the Council and in respect solely of the procedural stipulations contained in that Article.

Such a request must be made within one month from the date of such determination. The Court shall rule within one month from the date of the request.

3) fr.: La Cour de justice n'est compétente pour se prononcer sur la légalité d'un acte adopté par le Conseil européen ou par le Conseil en vertu de l'article 7 du traité sur l'Union européenne que sur demande de l'État membre qui fait l'objet d'une constatation $d u$ Conseil européen ou du Conseil, et qu'en ce qui concerne le respect des seules prescriptions de procédure prévues par ledit article.

Cette demande doit être faite dans un délai d'un mois à compter de ladite constatation. La Cour statue dans un délai d'un mois à compter de la date de la demande.

11 Zob. też K. Scheuring w komentarzu do art. 269 TFUE [w:] Traktat o funkcjonowaniu Unii Europejskiej. Komentarz, red. A. Wróbel (całość), t. III (art. 223-358), red. D. Kornobis-Romanowska, J. Łacny, Warszawa 2012, s. 435-439.

12 Tak również F.-X. Priollaud, D. Siritzky, Le Traité de Lisbonne, op. cit., s. 50; a także S. Mangiameli, G. Saputelli, Article 7 [w:] The Treaty on European Union (TEU). A Commentary, red. H.-J. Blanke, S. Mangiameli, Heidelberg-New York 2013, s. 363. Podobnie L. Besselink, The Bite, the Bark and the Howl: Article 7 and the Rule of Law Initiatives [w:] The Enforcement of EU Law and Values: Ensuring Member States' Compliance, red. A. Jakab, D. Kochenov, Oxford 2017, s. 128 i n., według którego przed traktatem z Lizbony zalecenia mogły być wydawane także razem ze stwierdzeniem wyraźnego ryzyka. Rewizja lizbońska wprowadziła sekwencję czasową (The text since 
nie mogą stanowić części stwierdzenia wyraźnego ryzyka. Stwierdzenie wyraźnego ryzyka naruszenia art. 2 TUE powinno zawierać zatem jedynie samo stwierdzenie (ustalenie istnienia) wyraźnego ryzyka (zagrożenia) i jego uzasadnienie (powody ustalenia jego istnienia). Nie zawiera i nie może ono zawierać zaleceń. Odrębność zaleceń i stwierdzenia wyraźnego ryzyka jako odrębnych aktów Rady potwierdzają jednoznacznie inne wersje językowe art. 7 ust. 1 TUE, które nie pozostawiają wątpliwości, że gdyby Rada Unii Europejskiej zamierzała udzielić najpierw państwu członkowskiemu zaleceń, musi zastosować taką samą procedurę jak w przypadku stwierdzenia wyraźnego ryzyka. Nie byłoby potrzeby ponownego przeprowadzania procedury, gdyby chodziło o przyjęcie tylko jednego aktu. Tymczasem w opiniowanym projekcie doszło do jednoczesnego stwierdzenia wyraźnego ryzyka i sformułowania zaleceń, co stanowi istotne naruszenie art. 7 ust. 1 TUE zarówno z uwagi na uchybienia formalne (proceduralne), jak i materialne (powiązanie stwierdzenia wyraźnego ryzyka i zaleceń).

\section{Skutki prawne dokumentów UE}

Wadliwy charakter projektowanej decyzji Komisji utrudnia ocenę skutków. Sprzeczność projektowanej decyzji z TUE powinna być zakwestionowana przez Parlament Europejski w toku procedury wyrażania zgody, o której mowa w art. 7 ust. 1 TUE, albo podważona przez Trybunał Sprawiedliwości w toku procedury następczej, o której mowa w art. 269 TFUE.

Gdyby jednak doszło do przyjęcia decyzji (po bezskutecznym, zdaniem Rady, upływie wskazanego w niej terminu), to wówczas możliwe byłoby podjęcie dalszych kroków. W pierwszym rzędzie sprawa zostałaby przedłożona Radzie Europejskiej, która mogłaby, na wniosek $1 / 3$ państw członkowskich lub Komisji i za zgodą Parlamentu Europejskiego oraz po wysłuchaniu zainteresowanego państwa członkowskiego, stwierdzić jednomyślnie poważne i stałe naruszenie wartości, o których mowa w art. 2 TUE (art. 7 ust. 2 TUE). To z kolei otwierałoby drogę do ewentualnych dalszych decyzji (ponownie) Rady Unii Europejskiej (np. decyzji na podstawie art. 7 ust. 3 TUE).

Lisbon clearly suggests that recommendations can be made before the existence of such a risk has been determined, albeit under the same procedure as for that determination. This suggests the competence of the Union prior to the risk determination). Do takiego wniosku prowadzi również wykładnia historyczna, dotycząca brzmienia art. 7 TUE sprzed traktatu z Lizbony. Zalecenia i stwierdzenie wyraźnego ryzyka były tam powiązane. Zob. też C. Mik w komentarzu do art. 7 [w:] C. Mik, W. Czapliński, Traktat o Unii Europejskiej. Komentarz, Warszawa 2005, s. 93-100. Nie jest natomiast trafne stanowisko F. Schorkopfa, op. cit., s. 10, zgodnie z którym Radzie pozostawiono swobodę uznania, czy chce powiązać stwierdzenie wyraźnego ryzyka z zaleceniami. Nie bardzo jednak wiadomo, jak autor doszedł do takiego wniosku po lekturze art. 7 ust. 1. Warto przypomnieć, że postanowienia kompetencyjne, nawet te, które dają pewną władzę uznaniową, wymagają wykładni zwężającej, a nie rozszerzającej. 


\section{Kwestie proceduralne}

\section{- Procedura przyjmowania dokumentów UE}

Projektowana decyzja ma być przyjęta przez Radę Unii Europejskiej. W trakcie podejmowania decyzji Rada stanowi większością 4/5 członków Rady, bez udziału Polski (art. 354 ust. 1 TFUE).

Analizowany dokument UE został przyjęty przez Komisję 20 grudnia 2017 r. i tego samego dnia przekazany do Rady i Parlamentu Europejskiego. Następnego dnia, tj. 21 grudnia 2017 r., dokument ten został przesłany do Sejmu.

Projekt decyzji nie podlega ocenie z punktu widzenia zgodności z zasadą pomocniczości w trybie określonym w art. 6 protokołu (nr 2) w sprawie stosowania zasad pomocniczości i proporcjonalności, ponieważ nie jest projektem aktu prawodawczego UE.

\section{- Działania Komisji ds. Unii Europejskiej}

Komisja Europejska zakwalifikowała projektowany akt jako decyzję Rady. Zgodnie z art. 8 ust. 1 ustawy z 8 października 2010 r. o współpracy Rady Ministrów z Sejmem i Senatem w sprawach związanych z członkostwem Rzeczypospolitej Polskiej w Unii Europejskiej (Dz.U. nr 213, poz. 1395; dalej ustawa) Rada Ministrów ma obowiązek przekazać Sejmowi projekt aktu prawnego UE innego niż akt, o którym mowa w art. 7 ust. 1 i 2 ustawy (akt prawodawczy i akt wydawany na podstawie art. 352 TFUE). Dodatkowo, zgodnie z tym przepisem, na żądanie Komisji ds. Unii Europejskiej, w terminie 14 dni od dnia otrzymania żądania Rada Ministrów przedstawia projekt stanowiska RP dotyczący takiego projektu.

W dniu 12 stycznia 2018 r. Komisja ds. Unii Europejskiej wystąpiła o przedstawienie projektu stanowiska w tym trybie. Projekt stanowiska RP do projektowanej decyzji nie został do dnia sporządzenia niniejszej opinii przesłany do Sejmu.

Zgodnie $\mathrm{z}$ art. 8 ust. 2 ustawy po otrzymaniu projektu stanowiska RP Komisja ds. Unii Europejskiej może w terminie 21 dni od dnia przekazania Sejmowi projektu stanowiska do tego aktu wyrazić opinię o projekcie aktu prawnego UE. W związku z nieprzesłaniem przez Radę Ministrów projektu stanowiska RP dotyczącego projektowanej decyzji Rady termin ten nie zaczął jeszcze płynąć.

\section{Wnioski}

Sejm RP powinien zwrócić uwagę na wadliwość prawną projektowanej decyzji.

W razie jej przyjęcia Polska powinna zaskarżyć ją do Trybunału Sprawiedliwości UE. 


\section{Bibliografia}

Geiger R., Komentarz do art. 7 Traktatu o Unii Europejskiej [w:] European Union Treaties. A Commentary. Treaty on European Union. Treaty on the Functioning of the European Union. Charter of Fundamental Rights of the European Union, red. R. Geiger, D.-E. Khan, M. Kotzur, München-Oxford 2015.

M. Ruffert, Komentarz do art. 7 [w:] E. Grabnitz, M. Hilf, M. Nettesheim, Das Recht der Europäischen Union, München 2012-2014.

Mangiameli S., Saputelli G., Article 7 [w:] The Treaty on European Union (TEU). A Commentary, red. H.-J. Blanke, S. Mangiameli, Heidelberg-New York 2013, https://doi. org/10.1007/978-3-642-31706-4_8.

Mik C., Komentarz do art. 7 [w :] C. Mik, W. Czapliński, Traktat o Unii Europejskiej. Komentarz, Warszawa 2005.

Mik C., Opinia na temat pojmowania aktów ustawodawczych i znaczenia tego pojęcia dla pozycji parlamentów narodowych w Unii Europejskiej, „Zeszyty Prawnicze BAS” 2010, nr 2.

Priollaud F.-X., Siritzky D., Le Traité de Lisbonne. Texte et commentaire article par article des nouvaux traités européens (TUE-TFUE), Paris 2008.

Scheuring K., Komentarz do art. 269 TFUE [w:] Traktat o funkcjonowaniu Unii Europejskiej. Komentarz, red. A. Wróbel (całość), t. III (art. 223-358), red. D. Kornobis-Romanowska, J. Łacny, Warszawa 2012. 